\title{
Isolated sulfite oxidase deficiency: a founder mutation
}

\author{
Aizeddin A. Mhanni, ${ }^{1}$ Cheryl R. Greenberg, ${ }^{1,2}$ Elizabeth L. Spriggs, ${ }^{1,2}$ \\ Ronald Agatep, ${ }^{2}$ Reena Ray Sisk, ${ }^{3}$ and Chitra Prasad ${ }^{4}$ \\ ${ }^{1}$ Department of Pediatrics and Child Health, ${ }^{2}$ Department of Biochemistry and Medical Genetics, University of \\ Manitoba, Winnipeg, Manitoba R3A 1S1, Canada; ${ }^{3}$ Saskatoon Health Authority, Saskatoon S7K 0M7, Canada; \\ ${ }^{4}$ London Health Sciences Centre, Western University, London, Ontario N6A 5A5, Canada
}

\begin{abstract}
Isolated sulfite oxidase deficiency is a rare autosomal recessive inborn error of sulfur metabolism. Clinical features generally include devastating neurologic dysfunction, ectopia lentis, and increased urinary excretion of sulfite, thiosulfate, and S-sulfocysteine. Missed diagnosis is not unusual because of variability in the sensitivity of the urinary sulfite and thiosulfate screening test. We present clinical, biochemical, and molecular data on two unrelated patients with isolated sulfite oxidase deficiency. The two patients belong to an Indigenous genetic isolate in Manitoba, Canada. Both patients (one male and one female, both now deceased) developed neonatal seizures and demonstrated progressive neurodevelopmental delay. Based on increased urinary excretion of sulfite, thiosulfate, and S-sulfocysteine and normal serum uric acid levels, sulfite oxidase deficiency was suspected. Both patients have a homozygous 4-bp deletion, 1347-1350delTTGT in the sulfite oxidase gene (SUOX), predicting a premature termination of the sulfite oxidase protein leading to absence of the carboxy-terminal third portion of the protein. This domain contains most of the contact sites essential for enzyme dimerization. This deletion mutation resulted in sulfite oxidase deficiency with early-onset severe clinical phenotype.
\end{abstract}

Corresponding author: amhanni@hsc.mb.ca

(C) 2020 Mhanni et al. This article is distributed under the terms of the Creative Commons Attribution-NonCommercial License, which permits reuse and redistribution, except for commercial purposes, provided that the original author and source are credited.

Ontology terms: increased urinary sulfite; increased urinary thiosulfate

Published by Cold Spring Harbor Laboratory Press

doi:10.1101/mcs.a005900

\section{CASE PRESENTATION}

The clinical and biochemical data on the two patients are presented in Tables 1 and 2, respectively.

\section{TECHNICAL ANALYSIS}

Genomic DNA was isolated from cultured fibroblasts and/or blood samples, and the gene encoding SUOX was amplified by polymerase chain reaction (PCR) using standard conditions. PCR primers spanning the entire coding region (CCTCAAGGATCTGCATTCAGGCC and AAGGGGTGGAGGTGGCTCCTTTCC) were included at a concentration of $1 \mu$ molar, and the reaction was cycled for $30 \mathrm{sec}$ at $55^{\circ}$, for $5 \mathrm{~min}$ at $68^{\circ}$, and for $30 \mathrm{sec}$ at $95^{\circ}$ for a total of 35 cycles. The entire reaction mixture was run on an agarose gel and the band at $\sim 2.4 \mathrm{~kb}$, corresponding to the sulfite oxidase gene with its single intron, was extracted from the gel and sequenced in both the forward and reverse directions. Automated DNA sequencing was performed at the Duke University Comprehensive Cancer Center facility using a PerkinElmer/ABI 377 DNA Sequencer and Big Dye sequencing chemistry. Numbering of nucleotides is based on the cDNA sequence, with the A of the ATG initiator methionine codon 
Table 1. Clinical findings

\begin{tabular}{|c|c|c|c|c|c|c|c|}
\hline Patient & $\begin{array}{c}\text { Age at } \\
\text { presentation }\end{array}$ & Sex & Symptoms & $\begin{array}{l}\text { Lens } \\
\text { dislocation }\end{array}$ & Family history & $\begin{array}{c}\text { Ethnic } \\
\text { background }\end{array}$ & $\begin{array}{l}\text { Current } \\
\text { status }\end{array}$ \\
\hline 1 & First week & $\mathrm{F}$ & $\begin{array}{l}\text { Intractable seizures, severe } \\
\text { developmental delay, spastic } \\
\text { quadriplegia }\end{array}$ & Not assessed & Negative & Indigenous & $\begin{array}{l}\text { Deceased at } \\
9 \mathrm{yr}\end{array}$ \\
\hline 2 & $5 d$ & M & $\begin{array}{l}\text { Lethargy, hypotonia, severe } \\
\text { developmental delay, } \\
\text { intractable seizures }\end{array}$ & Not assessed & $\begin{array}{l}\text { Possible affected } \\
\text { older sibling based } \\
\text { on history }\end{array}$ & Indigenous & $\begin{array}{l}\text { Deceased at } \\
15 \mathrm{mo}\end{array}$ \\
\hline
\end{tabular}

denoted nucleotide +1 . Numbering of the amino acids is also from the initiator methionine, which is the first amino acid in the 22-residue leader sequence of sulfite oxidase.

\section{VARIANT INTERPRETATION}

Both patients have a homozygous 4-bp deletion, 1347-1350delTTGT in the sulfite oxidase gene (SUOX), predicting a premature termination of the sulfite oxidase protein leading to absence of the carboxy-terminal third portion of the protein. This domain contains most of the contact sites essential for enzyme dimerization. The parents are heterozygous for this variant. This novel variant in SUOX likely is a founder mutation, given its presence in two unrelated Indigenous children from the same genetic isolate (Table 3).

Isolated sulfite oxidase deficiency (MIM 272300) is an autosomal recessive disorder caused by mutations in the sulfite oxidase gene (SUOX), GenBank accession number AY056018. The gene is located on Chromosome 12, in the region of 12q13.2, and the coding sequence contains a single intron. The gene product, sulfite oxidase, is a molybdohemoprotein comprised of 466 amino acids. It is synthesized with a 22-residue leader sequence that directs it to the mitochondrial intermembrane space. The mature protein lacks this presequence. The native enzyme is a dimer of identical subunits, each of which contains three domains-the amino-terminal heme domain, the central molybdenum domain, and a carboxy-terminal domain with key residues at the dimer interface (Johnson and Rajagopalan 1976; Kisker et al. 1997). The enzyme catalyzes the oxidation of sulfite to sulfate, the terminal reaction in the degradation of sulfur-containing amino acids, and transfers the electrons derived from substrate oxidation to cytochrome $c$ on the inner mitochondrial membrane.

Sulfite oxidase deficiency is classically characterized by severe neurological symptoms including seizures, often refractory to anticonvulsant medications, and rapidly progressing

\begin{tabular}{|c|c|c|c|c|c|c|c|c|}
\hline $\begin{array}{l}\text { Analyte } \\
\text { (normal } \\
\text { range) }\end{array}$ & $\begin{array}{l}\text { Urine S-sulfo- } \\
\text { cysteine }(<25 \\
\mu \mathrm{mol} / \mathrm{mmolCr})\end{array}$ & $\begin{array}{l}\text { Urine sulfite } \\
\text { (not detected) }\end{array}$ & $\begin{array}{c}\text { Plasma } \\
\text { cystine } \\
(23-49 \\
\mu \mathrm{mol} / \mathrm{L})\end{array}$ & $\begin{array}{c}\text { Serum uric } \\
\text { acid (130- } \\
330 \mu \mathrm{mol} / \mathrm{L})\end{array}$ & $\begin{array}{c}\text { Xanthine } \\
\text { hypoxanthine }\end{array}$ & Cranial MRI & $\begin{array}{l}\text { Enzyme } \\
\text { activity } \\
\text { (liver) } \\
(7-28 \mu / g)\end{array}$ & $\begin{array}{l}\text { Molecular } \\
\text { diagnosis }\end{array}$ \\
\hline Patient 1 & Small peak & 80-400 mg/L & 5 & 162 & Normal & $\begin{array}{l}\text { Agenesis of } \\
\text { corpus } \\
\text { callosum }\end{array}$ & 0 & 1347-1350delTTGT \\
\hline Patient 2 & 131 & $40 \mathrm{mg} / \mathrm{L}$ & 4 & 187 & Normal & $\begin{array}{l}\text { Giant } \\
\text { cisterna } \\
\text { magna }\end{array}$ & Not done & 1347-1350delTTGT \\
\hline
\end{tabular}


Table 3. Genomic findings

\begin{tabular}{|c|c|c|c|c|c|c|c|}
\hline Disease & Gene & Inheritance & HGVS cDNA & NM & Mutation & Protein & $\begin{array}{l}\text { Variant } \\
\text { interpretation }\end{array}$ \\
\hline $\begin{array}{l}\text { Sulfite oxidase } \\
\text { deficiency }\end{array}$ & SUOX & $\begin{array}{l}\text { Autosomal } \\
\text { recessive }\end{array}$ & $\begin{array}{l}\text { NC_000012.11: } \\
\text { g.56398694_56398697delTTGT }\end{array}$ & $\begin{array}{l}\text { NM_000456.2: } \\
\text { c.1521_1524delTTGT }\end{array}$ & c.1521_1524delTTGT & p.C508Rfs*109 & Pathogenic \\
\hline
\end{tabular}

Competing Interest Statement

The authors have declared no competing interest.

\section{Referees}

Andreas Schulze

Anonymous

Received October 12, 2020; accepted in revised form November 5, 2020. to an encephalopathic state. A significant proportion of patients develop complete or partial ectopia lentis. Although milder cases have been described, in the classic presentation, death occurs at an early age, and none of the treatments tested to date improved the clinical outcome (Johnson and Duran 2001). The preliminary diagnosis is made by elevated urinary sulfites, increased excretion of thiosulfate, increase in S-sulfocysteine, and normal serum uric acid, xanthine, and hypoxanthine. Confirmatory diagnosis is made by measuring sulfite oxidase activity in liver or fibroblasts or identifying a disease-causing mutation in SUOX. To date there have been 21 missense/nonsense mutations, seven small deletions, and one small insertion in SUOX reported in individuals with isolated sulfite oxidase deficiency (HGMD). The mutation identified here resulted in severe sulfite oxidase deficiency with early onset and severe clinical manifestations.

\section{SUMMARY}

It is important to consider isolated sulfite oxidase deficiency/molybdenum cofactor deficiency particularly when dealing with severe seizures and developmental delay in infancy. Screening of fresh urine for sulfites is a simple test but has false positives and false negatives. Urine for thiosulfate can be falsely positive with sulfur containing antibiotics and some anticonvulsants. Urine screening for S-sulfocysteine is more reliable. Uric acid is normal in isolated sulfite oxidase deficiency as compared to molybdenum cofactor deficiency, in which it is usually low. Cranial MRI and EEG are usually abnormal although not diagnostic. The mutation described here of a 4-bp deletion 1347-1350delTTGT in SUOX, in two unrelated Indigenous patients predicts a premature termination of the sulfite oxidase protein. Carrier screening for this deletion mutation will be offered to the patients' extended families.

\section{ADDITIONAL INFORMATION}

\section{Data Deposition and Access}

The variant has been submitted to ClinVar (https://www.ncbi.nlm.nih.gov/clinvar/) and can be found under accession number SCV001450523.

\section{Ethics Statement}

Verbal consent for publication from the families was obtained. We did not require Research Ethics Board approval as the molecular testing reported in this manuscript was done as part of standard clinical care.

\section{Acknowledgments}

We thank Dr. K. Rajagopalan and Dr. J.L. Johnson from the Department of Biochemistry, Duke University Medical Center for the initial molecular studies. We thank the patients and their families for their cooperation. 


\section{Author Contributions}

A.A.M., C.R.G., and C.P. oversaw patient care, data collection, data analysis, genetic interpretation, and writing the original draft preparation. R.R.S. assisted with the molecular analysis. E.L.S. and R.A. verified the accuracy of the molecular nomenclature and helped submit the variant to ClinVar. All coauthors read and approved the manuscript.

\section{Funding}

Work at Duke University Medical Center was supported by a National Institutes of Health (NIH) Grant 61444283.

\section{REFERENCES}

Kisker C, Schindelin H, Pacheco A, Wehbi WA, Garrett RM, Rajagopalan KV, Enemark JH, Rees DC. 1997. Molecular basis of sulfite oxidase deficiency from the structure of sulfite oxidase. Cell 91: 973-983. doi:10.1016/S0092-8674(00)80488-2

Johnson JL, Duran M. 2001. Molybdenum cofactor deficiency and isolated sulfite oxidase deficiency. In The metabolic and molecular bases of inherited disease, 8th ed. (ed. Scriver CR, Beaudet AL, Sly WS, Valle D), pp. 3163-3177. McGraw-Hill, New York.

Johnson JL, Rajagopalan KV. 1976. Human sulfite oxidase deficiency: characterization of the molecular defect in a multicomponent system. J Clin Invest 58: 551-556. doi:10.1172/JCl108500 


\section{$\$_{\text {CSH }}^{\infty}$ C O L D S P R I n G H A R B O R
$\$_{\infty} \&_{\text {Molecular Case Studies }}$}

\section{Isolated sulfite oxidase deficiency: a founder mutation}

Aizeddin A. Mhanni, Cheryl R. Greenberg, Elizabeth L. Spriggs, et al.

Cold Spring Harb Mol Case Stud 2020, 6: a005900

Access the most recent version at doi: $10.1101 / \mathrm{mcs} . a 005900$

\begin{tabular}{cl}
\hline License & $\begin{array}{l}\text { This article is distributed under the terms of the Creative Commons } \\
\text { Attribution-NonCommercial License, which permits reuse and redistribution, except } \\
\text { for commercial purposes, provided that the original author and source are credited. } \\
\text { Email Alerting } \\
\text { Service }\end{array}$ \\
$\begin{array}{l}\text { Receive free email alerts when new articles cite this article - sign up in the box at the } \\
\text { top right corner of the article or click here. }\end{array}$ \\
\hline
\end{tabular}

